\title{
From the Streets to the Mountains: The Dynamics of Transition from a Protest Wave to an Insurgency in Kashmir
}

\author{
Tijen Demirel-Pegg
}

Indiana University-Purdue University Indianapolis

\begin{abstract}
This study investigates the dynamics of transition from a peaceful protest wave to a violent insurgency. It examines the causal path leading to a major shift in the intensity of a protest wave and argues that the transition is the product of the interactions between the dissidents, the state, and external actors. By studying the protest wave in Kashmir (1979-1988), it identifies state repression and external support as the key factors driving the transition process. Time series analysis is used to analyze the original empirical evidence collected through content analysis. By providing a comprehensive understanding of the origins of the insurgency in Kashmir, this study shows that protest waves and civil wars are intimately linked.
\end{abstract}

\section{Published in Mobilization}

This is the author's manuscript of the article published in final edited form at:

Demirel-Pegg, Tijen (2014), "From the Streets to the Mountains: The Dynamics of Transition from a Protest Wave to an Insurgency in Kashmir", Mobilization, Vol. 19 (3), pp. 309-329. http://mobilization.metapress.com/ 
In December 2010, the self-immolation of a man in Tunisia triggered prodemocracy protests throughout the Arab world, leading to the mobilization of thousands of people against authoritarian regimes in the Middle East. While some of these protests were quelled, others succeeded in bringing on regime change; and some, such as those in Libya and Syria, transformed into civil wars.

Libya and Syria are among a host of civil war cases that initially began as protest waves. For instance, the civil wars in Guatemala (1960-1996), Nicaragua (1978-1990), and El Salvador (1981-1992) all evolved from widespread demonstrations and strikes (Brockett 2005; Lichbach, Davenport, and Armstrong 2003; Almeida 2008). In these cases, two forms of contention, protest waves and civil wars, were intimately connected. The question then becomes: what links these two? I maintain that protest waves and civil wars are linked by a dynamic process which is a product of the interactions between the dissidents, the state, and external actors.

Even though several studies have noticed the connection between protest waves and civil wars (Lichbach, Davenport, and Armstrong 2003; Sambanis and Zinn 2006; Tarrow 2007), the determinants of transition remain unclear. I argue that when the extremist wing of a protest wave gains support, it steers protest activity toward violent forms of collective action. As protest waves emerge and spread, non-governmental groups mobilize and compete against each other for recruits and resources, ratcheting up the willingness of groups to embrace more extreme strategies involving violence (Tarrow 1989). The potential for transition to a civil war occurs when governments use force to repress the dissidents. Ineffective or indiscriminate governmental repression can have 
disastrous effects leading to a spiral of conflict as protesters supplant nonviolent dissent with more violent forms (Opp and Roehl 1990; Lichbach 1987; White 1989). Meanwhile, foreign financial and military support to the rebels can dramatically increase dissident capabilities, thus elevating conflict intensity (Salehyan 2009; Gleditsch 2007).

Therefore, I argue that the transition to civil war happens when radical groups begin to take control of the protest wave, shifting to predominantly violent tactics.

This combination of state repression and external support has been at the core of several other cases as well. In El Salvador, the harsh repression by the state is widely noted (Brockett 2005; Almeida 2008). The external support provided by Nicaragua and other communist regimes in the early 1980s enabled the dissidents to arm their rebel forces and launch offensive strikes against the state (Brockett 2005). More recently, the protests in Syria against the Assad regime escalated to an insurgency as the protesters began receiving funding from the Syrian Diaspora, wealthy Sunni Muslims and sympathetic governments, including Saudi Arabia and Qatar (Entropy Increasing 2012). Using Tarrow's $(1989,1998)$ waves of contention framework, I study the dynamics of transition from the protest wave of the mid-1980s in the Indian state of Jammu and Kashmir (hereafter, Kashmir) to an insurgency in 1988. Insurgency, a type of civil war, is characterized by a power asymmetry between the insurgents and the government forces, in which the rebels typically lack sufficient military capabilities to confront the government forces directly (Kalyvas 2005). By focusing on the interactions between the dissidents, the state, and external actors, I demonstrate how the shift from a predominantly nonviolent form of contention to a violent one occurs in Kashmir. A 
protest wave which started out as mostly street demonstrations evolved into an insurgency in which rebels ambushed government forces and bombed buildings.

A defining facet of the transition process in this study is endogenous causation, which refers to the high degree of interdependence between the actions and responses of the actors (Beissinger 2011). The state's attempts to crush the protesters in Kashmir, the radicals' actions in the face of repression, and Pakistani support to the dissidents all interacted to create an escalatory dynamic. This ongoing process of tactical interaction in which the dissidents and the state try to offset each other's moves (McAdam 1983) prioritizes these dynamics and downplays the effects of structural conditions.

The theoretical contributions of this study are threefold. First, it represents the first effort to focus precisely on the dynamics of the transition from a nonviolent form of contention into a violent one - something that earlier works on contentious politics have largely neglected. Second, it makes the theoretical case that two types of political contention, protest waves and insurgencies are inherently linked. Political scientists and sociologists have typically approached these two phenomena as relatively distinct (Tarrow 2007). For instance, Kalyvas (2006) maintains that protests and civil war dynamics are separate as contentious politics are characterized by the monopoly of violence by the state while civil war takes place in the absence of such a monopoly. Nonetheless, this study shows that similar factors occur in protest waves and insurgencies and that both protest waves and insurgencies can be seen as different phases of a larger episode of a conflict (Tarrow 2007; Tilly and Tarrow 2007; McAdam, Tarrow, and Tilly 2001). The contentious politics and civil war literatures generally do not explain the 
dynamics of the transition period well. Therefore, uncovering these dynamics in the Kashmir case is an important first step to understanding this transformative process. Finally, this study modifies Tarrow's $(1989,1998)$ waves of contention framework to include the possibility of transition into an insurgency. Tarrow's model suggests that a protest wave reflects a parabolic trajectory with a relatively regular rise and fall of protest activity as demobilization sets in after protests reach their peak levels (Tarrow 1989). This study shows that in some situations nonviolent contentious activity can evolve into an insurgency without entering a demobilization phase.

The remainder of this article comprises five main sections. First, I explain why the Kashmir case is an ideal setting to understand the linkages between protest waves and the emergence of an insurgency. In the next section, I lay out the conceptual and theoretical foundations of the study. I then explain the research design, the construction of my own dataset, and finally discuss the empirical results. Overall, the findings show that the main driving force of the transition to civil war in Kashmir is the state's indiscriminate and direct repressive tactics combined with the support the dissidents received from Pakistan. When the state repressed the nonviolent dissidents, Pakistan provided substantive support to the radical dissidents, enabling them to organize violent attacks against the state. As collective action turned more violent, the state continued to repress the dissidents, further fueling violent collective action, transforming a nonviolent protest wave to an insurgency. In the conclusion, I discuss the broader implications of these findings for the study of contentious politics. 


\section{WHY KASHMIR?}

Kashmir is a case of a transition from a protest wave to an insurgency that was facilitated by foreign support, providing a unique opportunity for studying the dynamics of the transition process for three main reasons. First, Kashmir is an interesting deviant case because repression not only failed to demobilize the protest wave, but also contributed to the shift from nonviolent protests to an insurgency. This outcome is highly unusual as most states that are willing to repress and have the capabilities to do so usually succeed in demobilizing popular contention (Brockett 2005). Kashmir is a nice contrast to the cases that de-escalate. Moreover, the transition process in Kashmir is an important contrast demonstrating that insurgencies do not only occur out of static conditions as many structural approaches in the civil war literature suggest (Collier and Hoeffler 2004; Fearon and Laitin 2003); but evolve as a result of a sequence of political interactions between the dissidents and the state (Lichbach, Davenport, and Armstrong 2003). By using fine-grained data, I show the dynamics of this process in Kashmir. ${ }^{1}$

Second, the stages of transition to an insurgency are easily identifiable in the Kashmiri case. As Figure 1 illustrates, the protest wave first started in mid-1980 as residents protested against the government's poor performance in Kashmir. Kashmiris were dissatisfied over a number of issues dealing with limited employment opportunities, a lack of economic development, corruption, and nepotism. Moreover, increased literacy and the expansion of mass media had produced a generation of politically aware Kashmiris. Without adequate institutional channels to express their discontent, this new generation of Kashmiri Muslims began to protest in the streets, raising slogans often 
intermingled with Islamic fundamentalism and secessionist sentiments (Ganguly 1997). Initially, the dissidents were loosely organized, and collective action remained at low levels until it suddenly began to expand in 1984. In mid-1986, protesters dramatically increased their activities, mostly using nonviolent tactics. Over the course of the protest wave, however, the protesters' initial strategy of expressing discontent became more violent as they broadened their goals to pursue Kashmiri independence. The State Assembly Elections held in March 1987 marked a turning point in the scale of violence. The National Conference and Congress(I) ran as an alliance against the Muslim United Front (MUF), a coalition of Islamic parties including Jamaat-e Islami, Ummat-e Islami, and the Anjuman-e Ittehad-ul Muslimeen (Swami 2007). The National Conference Congress (I) alliance won the majority of the seats; but the elections were deeply flawed as a result of voter intimidation and electoral fraud. The Islamic wing, therefore, concluded that there was no possibility for it to come to power through democratic means (Ganguly 1997). After 1987, the dissidents' tactics turned more radical. As Figure 1 shows, the intensity of political contention began to rise consistently starting in mid1988, marking the beginning of the insurgency as the Jammu Kashmir Liberation Front (JKLF) solidified its power and engaged in violent tactics against the state in pursuit of secessionist goals. These clear demarcations of the expansion and transition phases of contention allow for the examination of the transition from a protest wave to an insurgency. 
Finally, Kashmir is an important setting to study the dynamic of transition to an insurgency because it includes the role of foreign actors. In this case, Pakistan's support to Kashmiri dissidents had an important effect on the dynamics of the protest wave. Since a large majority of the literature on contentious politics focuses on internal or domestic dynamics (Tarrow 1989; Tilly and Tarrow 2007; Tilly 1978), the potential impact of foreign actors is frequently overlooked. Several studies on civil war onset, however, have found that external support can play an important role in the outbreak of an armed conflict (Gleditsch 2007; Salehyan 2009). Hence, Kashmir is an ideal case to examine two processes of protest wave formation and insurgency formation and to determine the relative importance of external support to the dissidents in comparison to other domestic factors such as state repression.

\section{DEFINING PROTEST WAVE AND INSURGENCY}

The delineation of conceptual boundaries between a protest wave and an insurgency is important because the transition has to capture the moment when the shift from one to the other occurs. I maintain that a protest wave and an insurgency are different ways for groups to engage in collective action, and are situated along a continuum of contentious politics. In both forms of conflict, actors coordinate their efforts to pursue their claims, influencing the behavior of other actors as well as the government. Yet, clear analytical differences between a protest wave and an insurgency can be identified mainly via the groups' selection of tactics. Thus, I define a protest wave as a series of interactions that extend over a long period of time in which actors take 
collective action against the state in pursuit of collective goals by using predominantly nonviolent tactics. ${ }^{2}$ The employment of violent tactics does not lie at the core of protest waves and, indeed, often signals their decline (della Porta and Tarrow 1986). So, on the contentious politics spectrum, a protest wave is situated toward the nonviolent end. Dissidents typically resort to demonstrations, boycotts, strikes, or sit-ins to raise their challenges against the state. The goals of the protestors are often non-revolutionary, although several protest waves have pursued revolutionary goals and led to regime changes such as the demonstrations in Leipzig in the former German Democratic Republic in 1989, or as most recently witnessed in Egypt and Tunisia. In protest waves, mass protests involve the participation of various sectors of the society such as students and workers, who are mostly peaceful and unarmed. Conversely, insurgency is a type of a civil war. Insurgency refers to an armed conflict within the boundaries of a recognized sovereign state, which takes place between the government and parties seeking to replace it or secede from it, and is conducted by irregular forces engaging in guerrilla tactics. In insurgencies, the rebels target the state militarily. Nonetheless, they lack the military capabilities to engage in conventional warfare and, therefore, attack vulnerable police and military targets or ambush military units, thus avoiding large-scale direct clashes with a conventionally organized government force (Snow 1996). It is the power asymmetry between the state and its challengers that defines the types of tactics used throughout an insurgency (Kalyvas 2005). Insurgents usually operate in rural areas where they enjoy popular support and state forces find it difficult to penetrate effectively (Snow 1996), challenging the state by organizing military ambushes, bomb explosions, arson, and 
limited armed clashes with security forces. In short, violence is a central part of contention in insurgencies. Thus, an insurgency is located toward the violent end of the contentious politics spectrum.

\section{DYNAMICS OF PROTEST WAVES: TARROW'S MODEL}

Tarrow's $(1989,1998)$ protest wave model comprises two phases: expansion and contraction. Accordingly, protest waves begin when the political environment provides incentives for collective action. Throughout this initial phase, existing organizations initiate protest activity by utilizing conventional repertoires of contention, including demonstrations and strikes. The diffusion of protests to different sectors and locations leads to more frequent and widespread protests. Established groups, such as trade unions, monopolize the use of conventional repertoires as they enter the wave, pushing new groups that are trying to differentiate themselves from established organizations, to resort to more confrontational tactics (Tarrow 1989). In particular, small organizations with extremist agendas turn to more radical and violent forms of contentious action. Ironically, the protest wave begins to contract when it appears to be at its utmost strength (della Porta and Tarrow 1986). Once protest activity has expanded, people become weary of protesting. Protests start to decelerate as participation and the frequency of events declines. Group competition for mass support also leads to polarization between the moderate and radical factions. While moderate groups opt for peaceful forms of contention through institutional channels such as forming political parties, radical groups continue to confront the state through violent means. Eventually, 
the protest wave ends as the radicals either lose mass support or continue to challenge the state by engaging in clandestine activities even as mass protests wither.

Several studies have found more diverse outcomes for protest waves than simply de-escalation. For instance, Beissinger (2002) examines the protest wave leading to the disintegration of the Soviet Union while Almeida (2008) focuses on the contentious activities in El Salvador which turned into a civil war in the early 1980s. Both studies show that protests can evolve into more intense forms of conflict depending upon the political opportunity structures, institutional constraints, levels of state repression and, in Beissinger's case, the momentum created by the initial protests. This study also questions the inevitability of de-escalation but differs from these studies in three major ways. First, it focuses on a particular segment of a contentious wave where nonviolent protests have already expanded and tactics are becoming violent instead of examining the entire wave structure starting from its origins and the expansion of nonviolent protests all the way to the end of the civil war. Second, while these two studies refer to accommodation and repression within larger contexts of political opportunity and threat, I highlight the dayto-day interactions of the state and the dissidents to understand the dynamics of contention. Finally, I also examine the effects of foreign actors on the transition process. An important element of Tarrow's model is the timing of contention. Actors' responses to external conditions and to each other depend heavily upon the phase of the protest wave. In this study, temporal location is crucial for analyzing the transition to an insurgency because the shift in conflict intensity happens when protest activity has 
expanded, but has not entered the contraction phase. Thus, I test my hypotheses through the expansion phase of the protest wave into the formation of the insurgency (Figure 2).

//Figure 2 about here//

\section{DYNAMICS OF TRANSITION FROM PROTEST WAVE TO INSURGENCY}

\section{The Determinants of Transition from a Protest Wave to an Insurgency}

I argue that both state repression and external support lead to the transition from a protest wave to an insurgency. When a protest wave is already in its expansion phase and protests have accelerated, meaning that nonviolent contention has diffused across various sectors in the society and increased in frequency, repression is likely to drive the

dissidents to shift from nonviolent to violent tactics. The interjection of external support enables the dissidents to gain the military means necessary to engage in guerrilla tactics and take the protest wave in the direction of an insurgency. While the fueling effects of repression are well-studied in the existing literature, most of these arguments pertain to a protest wave (Francisco 1995; Khawaja 1993; Rasler 1996; Granovetter 1978). In the following sections, I examine how repression influences the shift from nonviolent to violent tactics during the expansion phase of a protest wave, and how external support facilitates this shift, preventing the protest wave from entering the contraction phase.

\section{State Repression}

While Tarrow $(1989,1998)$ associates repression with the downswing phase of the protest wave, studies have shown that repression affects the acceleration of the protest 
wave during the expansion phase by creating a backlash effect (Francisco 1995; Rasler 1996; Brockett 2005). Brockett (2005) claims that when a protest wave is underway, the state usually increases repression gradually to suppress the dissidents, leading to elevated levels of contentious activities, creating new grievances and intensifying the desire for revenge and justice. Even though the backlash effect explains the acceleration of protests, it fails to address how the shift from a protest wave to an insurgency occurs.

I maintain that substitution models (Lichbach 1987; Moore 1998) provide the most applicable theoretical foundation to understand how the protest wave evolves to an insurgency. According to Lichbach (1987), protesters modify their tactics based on costbenefit calculations. If certain tactics evoke repressive state responses increasing the cost of collective action, then the protesters switch tactics. Thus, when the state represses nonviolent protests, increasing the cost of nonviolent collective action, the rebels switch to violent tactics. The simultaneous decrease in nonviolent tactics and the increase in violent ones raise the overall level of conflict. Furthermore, micromobilization models suggest that even if repression initially deters protests by imposing costs on collective action, its deterrent effect is neutralized, or even reversed, if people are directly exposed to repression and are members of informal associations such as unions, opposition groups, or churches that are supportive of protests (Opp and Roehl 1990; White 1989; McAdam 1988). For people to engage in political violence, people must perceive repression to be illegitimate and expect others to do so, anticipating their support for organized violence with the belief that organized violence is a viable option (White 1989). Yet, the shift in support for political violence may not happen immediately. 
Micromobilization processes might take some time as people meet and interact with others who believe in the utility of political violence. Therefore, repression might have a lasting effect on increased levels of conflict intensity.

While repression is likely to play a significant role in the transition to an insurgency, treating repression as a general category of state response risks overgeneralization. States choose from a variety of tactics to respond to dissent. The effects of different types of repression might vary and, therefore, influence conflict dynamics in diverse ways. For instance, Tilly (1978) maintains that governments use repressive measures to raise the cost of organization by suspending newspapers or forbidding assemblies, while they use repressive measures, such as setting up barricades during protests, to directly raise the cost of collective action. In this regard, Koopmans (1997) offers a useful categorization based on the consistency, legitimacy, and aim of repressive actions. Accordingly, institutional repression represents "formal, more general, less direct, and usually legally sanctioned repressive measures taken by higher-level authorities"; whereas situational repression is "informal actions of lower-level state agents, most importantly the police, who in direct contact with protestors apply repression in a relatively spontaneous, ad-hoc manner” (Koopmans 1997: 153-4). Institutional repression targets the mobilizing structures of the rebel groups and is typically predictable, consistent, and seen as legitimate. Conversely, situational repression targets collective action directly and is more inconsistent.

Following Koopmans, I categorize the state's repressive actions into three distinct types to investigate the shift from nonviolent to violent tactics: preventive repression, 
reactionary repression, and arrests. These categories encompass the repressive tactics states use during the expansion phase of a protest wave when contention accelerates. Preventive and reactionary repressions largely correspond to Koopmans' institutional and situational repression categories respectively with the caveat that my category of reactionary repression includes an element of indiscriminate violence. Arguably, the likelihood of indiscriminate violence is higher in reactionary repression as the state cannot always easily identify and punish the dissidents. If, for instance, the police have a hard time controlling an unruly crowd, the chances of the police teargassing people indiscriminately are relatively high. Moreover, as the state resorts to greater repression to suppress the dissidents at the peak of the protest wave (Brockett 2005), the risk of the police using excessive force is particularly high. In contrast, in preventive repression, the state uses repression without directly engaging civilians. So, when curtailing the civil liberties of its citizens, the state does not come into direct contact with any of the protesters, and therefore, avoids indiscriminate violence. Finally, I create an "arrest" category as arrests can be sanctioned by both higher and lower-level authorities and, thus, can be difficult to categorize as either preventive or reactionary repression.

I expect reactionary repression and arrests to have two possible outcomes for the transition of a protest wave to an insurgency: 1) they will have immediate positive effects on the shift from nonviolent to violent actions; and 2) they will also have longer-lasting positive effects. By immediate, I refer to the instant effect of repression. The lasting effect corresponds to continuous effects for several days after repression occurs to allow for micromobilization process to take place in weekly religious gatherings (for example, 
Friday prayers at mosques) and private or professional group meetings. The exact duration of the impact is calculated in the analysis section. As substitution models suggest, when protest activity has accelerated in the expansion phase, the state's reactionary repressive actions will increase the costs of protest and lead to the substitution of nonviolent with violent tactics. I expect reactionary repression to have a lasting positive effect on the transition to insurgency as a result of the micromobilization process. People are more likely to perceive indiscriminate repression involving violence to be illegitimate (Goodwin 2001). The negative sentiments caused by the state's violent acts will only get reinforced as people come together in various venues and share their experiences. Eventually, more people will be convinced that violence is the only viable option left to either change the political system or to secede.

Arrests should also have a positive impact on the shift to violent tactics. This type of repression is likely to be effective through substitution because arrests impose costs on nonviolent tactics. Moreover, people who are arrested and their close family and friends can be motivated to use violence for extremist goals if they perceive the arrests to be illegitimate. Again, through the micromobilization process, arrests will likely have a lasting positive impact on the transition to insurgency.

In contrast, preventive repression is likely to reduce the risk of transition because it is consistent. By targeting the mobilizing structures of dissidents, this type of repression imposes costs on contention and makes the shift from nonviolent to violent contentious tactics more difficult (Goodwin 2001). If preventive repression successfully inhibits the momentum created by the protest expansion, then the radical wing will be 
unable to gain strength. As preventive repression will likely be perceived to be more legitimate, it will be harder to convince people that political violence is the only option left. Once the momentum of the protest wave is lost and the radicals are unable to gain control, protests will decelerate without turning violent. So, I expect preventive repression to have negative immediate and lasting effects on the chances of a protest wave transitioning to an insurgency.

\section{State Accommodation}

Accommodation refers to state actions which lower the group's cost of collective action (Tilly 1978). Several studies on accommodation have highlighted its positive, negative or non impact on protest activity (Oberschall 1994; Tarrow 1998; Inclan 2009; Rasler 1996). It remains unclear if state accommodation fuels protest and encourages violent tactics; or if it leads to demobilization by creating a split between the radicals and the moderates. Following Tarrow (1989), I argue that the state's accommodative actions, such as initiating negotiations, will have a negative effect on the transition to an insurgency. When the state accommodates nonviolent protesters before the radical wing has gained strength, protesters will be unwilling to shift to violence. Violent tactics typically lead to harsh government repression and therefore are costly. So, the protesters will be reluctant to switch to a more costly option (Shellman 2006). When the government makes concessions, the protesters will be reluctant to side with the radical wing and engage in political violence. Thus, I expect to see both immediate and lasting negative effects of the state's accommodative actions on transitioning to insurgency. 


\section{External Support}

According to McCarthy and Zald (1977), resources including external support are crucial in facilitating mobilization against the state. For dissidents to shift to insurgent tactics after protests have accelerated, they need to secure resources to attain sufficient military capabilities. These can be hard to acquire particularly because the state has greater coercive power and enjoys the ability to impose restrictions on the dissidents' attempts to mobilize. Therefore, groups often turn to outsiders to enhance their capabilities to fight (Heraclides 1990).

I expect external support to have a positive impact on the transition of a protest wave to an insurgency by increasing the radical groups' capabilities and providing them the opportunity to engage in violent tactics successfully. Studies on external support suggest that providing safe havens, military training and equipment, financial support and even political or diplomatic support can greatly alter the capabilities of extremists (Gleditsch 2007; Salehyan 2009; Heraclides 1990). Furthermore, if radicals convey to their fellow protesters that they can potentially succeed, more people will join them (Klandermans 1984). Even political support from a foreign government can boost support for the rebels (Thyne 2006). External support is likely to have both immediate and lasting effects. While certain types of external support, such as the provision of arms or financial support might immediately effect the transition, the provision of safe havens or military training might take time to take effect. Thus, I expect external support to have positive contemporaneous and lasting impacts on the transition of a protest wave to an insurgency. All hypotheses tested in this study are summarized in Table 1. 
//Table 1 around here//

\section{RESEARCH DESIGN}

\section{Data}

My analysis is based on data collected from the national daily newspaper the Indian Express from January 1, 1979 through December 31, 1988. Repressive and accommodative state actions, contentious and accommodative dissident actions, and actions of the external actors were coded for date, actor, location, target, number of participants, number of injured and number of deaths. The exact date, actor and the type of action had to be clear to be included in the dataset. The remaining categories were coded as long as the information was provided in the report. In total, 3,363 events were hand-coded by the author, hence removing potential issues of inter-coder reliability. All

events were then weighted based on Krain's (2000) scale ranging from 1 to $25 .{ }^{3}$ Finally, the data were aggregated in daily intervals. ${ }^{4}$

As the dataset is based on a single newspaper, two issues are likely to challenge its validity: underrepresentation of the frequency of the actual events and selection bias. These issues do not, however, pose significant problems. First, Indian Express had correspondents based in Kashmir throughout the protest wave reporting directly from the area. Therefore, the newspaper provided detailed information regarding a wide range of collective actions as the events unfolded, reducing the chance of underrepresentation. As the data show similar trends illustrated by scholars who have studied the protest waves in Kashmir in detail (Ganguly 1997; Schofield 2003), concerns for the dataset's validity were also minimized. Nonetheless, it is challenging to capture the extent of external 
support through newspaper data as such information is typically covert and not frequently picked up by media reports. Hence, external support is coded conservatively in that the only positive codings happen when either militants are arrested crossing the border, when they are captured with Pakistani weapons, or when officials publicly express support for the militants. The possible underrepresentation of external support potentially leads to the underestimation of the effect of this factor. As for the issue of selection bias, the longitudinal design of the study reduces potential challenges to external and internal validity. Assuming that there is selection bias, the data should be affected by this problem throughout the entire course of the conflict in the same way because they all originate from the same data source. ${ }^{5}$

\section{The Dependent Variable}

The dependent variable is conflict intensity, which is measured as the logit transformation of the ratio of the daily scores of violent collective action to total collective action (violent and nonviolent). ${ }^{7}$ The dependent variable will vary based on whether the collective actions are mainly nonviolent, as is usually the case with protest waves; or violent as in insurgencies. Thus, the minimum values of conflict intensity reflect days when collective actions such as organizing meetings; violations of curfew; and nonviolent strikes and demonstrations which are typically found in protest waves occur. The maximum values of conflict intensity, on the other hand, reflect days when actions such as clashes; abductions and executions; armed attacks; and bombings; actions that I expect to observe in insurgencies take place. 


\section{The Independent Variables ${ }^{8}$}

Reactionary Repression: This variable is measured as the total daily score of repressive actions of lower-level authorities directly confronting the dissidents. Reactionary repression includes the violent or nonviolent putdown of demonstrations; beating up dissidents; armed attacks; bombings, or burning houses and villages.

Arrests: This variable consists of the total daily scores of arrests of protesters and opposition leaders in relation to collective action.

Preventive Repression: Preventive repression consists of the total daily scores of repressive events sanctioned by higher-level authorities. This variable includes restriction of civil rights and liberties; seizing assets; setting up special courts; imposing curfews; and declaring martial law.

State Accommodation: This variable is measured as the total daily score of state concessions. It includes initiating negotiations; removing restrictive laws and regulations; granting amnesty; withdrawing the army; and incorporating the opposition into the government.

External Support: External support is measured as the total daily score of all the support extremist groups received from foreign actors. Various forms of diplomatic, humanitarian, and material support including supportive expressions in the international arena; granting asylum to dissidents; and providing sanctuary, training, financial support or arms, are events that are included to generate this variable.

Elections: I control for the effect of elections on conflict intensity. According to Tilly (1978), collective action increases around elections as the electoral process itself provides 
opportunities for the formation of new associations or the inclusion of previously excluded groups in the political system. Elections can also affect conflict intensity through sharpening ethnic divisions (Snyder 2000) or if they are or are suspected to be fraudulent (McAdam and Tarrow 2010). The election variable is a dummy variable coded 1 for two months before and after the elections were held. ${ }^{9}$

\section{Estimation: Single Error Correction Model}

I estimate a single-equation error correction model (ECM) to examine the transition, which directly estimates the rate at which the dependent variable changes to return to equilibrium when a change occurs in the independent variable(s) (De Boef and Keele 2008).

Utilizing an ECM is appropriate for three major reasons. First, the model is dynamic and accounts for past influences on future values. The model assumes that the values at time $t-1$ are related to the values at time $t$, which are then related to the values at time $t+1$. This assumption of dependence between the values of the variables and their lagged values allows for testing the effects of the explanatory variables on the dependent variable over time. Furthermore, an ECM enables me to test for both the immediate and longer term effects of the explanatory variables on the dependent variable (De Boef and Keele 2008). The immediate or short term effect refers to the influence of an independent variable which does not persist into the future, or the effect of a unit change in $\mathrm{X}_{t}$ on $Y_{t}$ at time $t$. The longer term effect refers to the continuous impact of an independent variable over some number of time periods. The effect of $\mathrm{X}$ on $\mathrm{Y}$ persists into the future but decays over time. So, its impact at time $t+3$ will be smaller than its effect at time $t+2$. 
The ability to assess the immediate and lasting influences of the independent variables on the dependent variable is especially advantageous given the theoretical foundations of the model, which expect the state's and the external actor's actions to have both short and long term impacts on conflict intensity. ${ }^{10}$ Second, estimating an ECM is appropriate because theories of contentious politics clearly distinguish between dependent and independent variables. The state's repressive and accommodative tactics as well as the actions of external actors are weakly exogenous to conflict intensity. As such, an ECM is proper because it allows for estimating the causal impact of each independent variable on the dependent variable. Finally, an ECM can be used with either stationary or nonstationary data (De Boef and Keele 2008). Even though analysts frequently use ECMs for estimating statistical relationships between two series which are non-stationary and cointegrated, De Boef and Keele (2008) show that ECMs may be used with stationary data as well. To test for stationarity in the variables included in the model, I conduct Augmented Dickey-Fuller tests for each variable. The test results indicate that (at the .05 alpha level) violent and nonviolent collective actions, all three types of state repression, as well as accommodation and external support are all stationary in their levels. Therefore, I conclude that a single ECM is suitable to test the immediate and lasting dynamics of the transition process.

I estimate the following single ECM for the protest wave in Kashmir: ${ }^{11}$

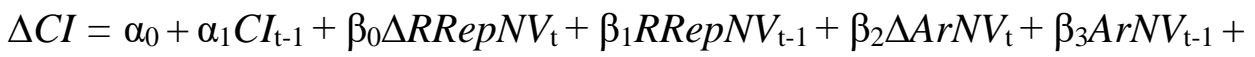

$$
\begin{aligned}
& \beta_{4} \Delta P \operatorname{RepN} V_{\mathrm{t}}+\beta_{5} P \operatorname{Rep} N V_{\mathrm{t}-1}+\beta_{6} \Delta \operatorname{SAccom}_{\mathrm{t}}+\beta_{7} \operatorname{SAccom}_{\mathrm{t}-1}+ \\
& \beta_{8} \Delta E x t S p t_{\mathrm{t}}+\beta_{9} E_{t} \operatorname{Spt} t_{\mathrm{t}-1}+\beta_{10} \text { Eletions }^{+} \varepsilon_{\mathrm{t}}^{12}
\end{aligned}
$$


where $C I$ represents the ratio of violent group collective actions to the total number of group collective actions. RRepNV, ArNV, PRepNV, SAccom, and ExtSpt correspond to reactionary repression of nonviolent actions, arrests of nonviolent actors, preventive repression of nonviolent actions, state accommodation, and external support respectively.

Elections is the dummy variable for election times. ${ }^{13}$ The rate at which the system returns to equilibrium after a change in the independent variables is represented by the ECM adjustment coefficient, $\alpha_{1}$. The coefficients $\beta_{0}, \beta_{2}, \beta_{4}, \beta_{6}$, and $\beta_{8}$ refer to the immediate effects of any change in the respective variables at time $t$ on the dependent variable. The lasting impacts of each type of repression of nonviolent actions, state accommodation, and external support are represented by the long run multiplier for each, which are calculated by dividing the coefficients of every lagged independent variable by the ECM adjustment coefficient.

\section{Findings $^{14}$}

Model 1 in Table 2 shows the results of the single $\mathrm{ECM}^{15}$ for the protest wave in Kashmir between 1979 and 1988 when nonviolent actions are repressed. ${ }^{16}$ For the short term effects, reactionary repression and external support have immediate and highly significant positive effects on conflict intensity. Arrests of nonviolent actors also increase conflict intensity but at a lower level of significance $(\mathrm{p}<.05)$. Contrary to my expectations, state accommodation and preventive repression have no significant effects on conflict intensity in the short term in Kashmir.

//Table 2 around here// 
Regarding the longer term influences, all the variables that have immediate significant effects in the short term have similar effects in their levels. Interestingly, preventive repression and accommodation increase conflict intensity when nonviolent collective action is targeted instead of decreasing it. These findings show that the fueling effects of preventive repression and accommodation were observed over the course of several days even though they did not have an immediate effect on conflict intensity.

The ECM adjustment coefficient estimating the rate at which the system returns to equilibrium after a change in the independent variables, is relatively high (-.73) and is highly significant, indicating that the system returns to equilibrium at a relatively fast rate following a temporary shock. The exact duration of the influence of every significant variable on conflict intensity can be computed through the long run multiplier (LRM). The LRM coefficients represent the total effects of their respective variables that are distributed over future time periods. The magnitude of the effect of each variable on conflict intensity diminishes at a rate of $73 \%$ at each subsequent day until their impact eventually wears off. For instance, the LRM for reactionary repression is $1.10 .{ }^{17}$ At $t$, reactionary repression will increase conflict intensity by .802 units; at $t+1$ by .217; at $t+2$ by .058 ; at $t+3$ by .016 , at $t+4$ by .004 , and by $t+5$ by .001 units. By the sixth day, the effect of reactionary repression fades away. Similarly, external support and accommodation continue to increase conflict intensity for five days before their effects wear off at $t+6$. As Table 3 shows, the effects of arrests and preventive repression continue to increase conflict intensity until $t+5$ when their effects diminish.

//Table 3 around here// 
Post-estimation simulations for expected values of conflict intensity in Model 1 further highlight the relative effects of the significant explanatory variables on the dependent variable. ${ }^{18}$ The results in Table 4 show that among the repression variables, reactionary repression of nonviolent collective action has the strongest immediate and lasting effects on conflict intensity. ${ }^{19}$ The expected value of conflict intensity is 3.366 when the change in reactionary repression (immediate effect) is at its highest value while all the other independent variables are held constant at their mean values. ${ }^{20}$ The longer term effect of reactionary repression is slightly higher with an expected value of conflict intensity of 3.662 when reactionary repression is at its highest value at $t-1$.

//Table 4 around here//

External support also has high contemporaneous and long term positive impacts on conflict intensity. The expected value for conflict intensity is 5.864 when the immediate change in external support is at its highest value. This variable's longer term impact is still strong with an expected value of 5.318 for conflict intensity when it was at its highest value. The total effect (11.177) is higher than the total influence of reactionary repression (7.022). Thus, the support the radicals in Kashmir received from Pakistan in terms of sanctuary, training, and arms transfers played a major role in the transition. ${ }^{21}$

The effects of arrest, preventive repression, and state accommodation are relatively moderate. For instance, the expected value of conflict intensity is 0.610 when the change in arrests is at its highest value. Its effect is still low in the longer term as the expected value of conflict intensity is at 0.968 when the change in arrests is at its highest value. 
A striking finding in the analysis is that the dynamics of conflict intensity are different when violent actions were repressed in Kashmir. Model 2 in Table 2 shows that all types of repression of violent actions have significant positive short and long term effects on conflict intensity. External support is also significant both in the short and long term when violent acts are repressed. In contrast to Model 1, accommodation decreases conflict intensity both in the short and long terms, suggesting that concessions were more effective in reducing the level of conflict intensity when the opposition had already switched to violence in Kashmir. Also, the ECM adjustment coefficient is higher in Model 2, indicating that the system goes back to equilibrium even faster and the long term effects of the significant variables wear off in a shorter time than they do when nonviolent actions are repressed. Most importantly, Model 2 shows that groups did not switch to nonviolent tactics as a result of the Indian state's repression of violent tactics. On the contrary, repression of violence significantly fueled the intensity of the Kashmiri conflict as groups continued to resort to violence. ${ }^{22}$

Another interesting finding is the insignificance of elections. While experts generally agree that the controversial State Assembly Elections of 1987 had a fueling effect on the conflict in Kashmir (Ganguly 1997; Swami 2007; Schofield 2003), the election variable is not significant as expected. This discrepancy with the literature can most likely be explained by the temporal aggregation of the time series. The data in this analysis are aggregated in daily intervals in an attempt to capture the relatively short-term dynamics. Nonetheless, the controversial elections most likely had longer term effects on the evolution the conflict. According to Ganguly (1997), the arrests of hundreds of MUF 
supporters right before the elections fueled conflict intensity in the following months by contributing to the grievances of the population and strengthening the support base of the radical wing. Such long term dynamics cannot be captured in this analysis.

Overall, the results of the single ECM and the post-estimation simulations for the expected values of conflict intensity indicate that repression of nonviolence, and in particular reactionary repression of nonviolence played a critical role in the transition of the protest wave to an insurgency in Kashmir. The defeat of MUF during the 1987 elections marked the beginning of a major shift toward violent tactics. Once the Islamic wing publicly expressed its secessionist ambitions, any pretext became a basis for protest activity which, quite often, resulted in violence. Unprepared to quell widespread collective action, the police usually tried to contain public demonstrations by resorting to violent crowd-control measures (Patankar 2009). These measures often evoked further violent protests particularly if people were injured or killed by the police. Therefore, these interactive dynamics between the protesters and the state led to a consistent upward spiraling of the conflict in Kashmir. For instance, in August 1987, a series of deadly clashes between the police and MUF activists took place while the leaders of MUF held a major public meeting in Srinagar urging people to join the struggle to establish an Islamic state (MUF Call to Scrap Accession 1987). Toward the end of the year, another round of agitation reflected the spiraling dynamics of conflict intensification in the region. In November, Chief Minister Farooq Abdullah announced his intention to stop alternating the state administrative hub annually between Jammu (largely Hindu) and Srinagar (largely Muslim) and switch to a permanent state administrative presence in Srinagar. 
This announcement led to a general strike in Jammu, initially organized by the Jammu Bar Association and supported by other influential political organizations. Faced with opposition, Farooq Abdullah reversed his decision. Subsequently, the MUF accused Farooq Abdullah of undermining the interests of Kashmiri Muslims (Ganguly 1997). Public demonstrations soon turned violent, with protesters throwing stones at a police station, and the police teargassing and beating up the protesters in response ("30 Hurt as 'Kashmir Bandh' turns violent" 1987).

The second critical aspect of the dynamics in Kashmir is Pakistani support to the radicals in the region. Once tension in Kashmir began to increase in 1987, Pakistan encouraged the JKLF to instigate an offensive struggle against the state (Staniland 2012). From February 1988 on, JKLF militants received training on the use of assault rifles and grenades in Pakistani camps (Swami 2007). As these militants returned to Kashmir, the types of attacks organized against the state changed. For instance, as Table 5 shows, incidents of bombings and arson increased in 1988 compared to the previous two years. Demonstrations and strikes also turned more violent in 1988 while the frequency of nonviolent forms of collective action declined. Even though my data do not always provide full confirmation that Pakistani-trained militants were indeed the ones who engaged in these violent actions, the strong relationship between external support and the increase in conflict intensity certainly points in that direction. As collective action became more violent, the state's repressive tactics also turned more violent, triggering more violent forms of mobilization and feeding into the spiral of conflict.

//Table 5 around here// 
In sum, the combination of the Indian state's repressive tactics and Pakistani support strengthened the radical wing and provided favorable conditions for the transition to an insurgency. This causal path is relatively similar to the one suggested earlier with the exception of the unanticipated fueling effect of preventive repression.

\section{CONCLUSION}

The results of the quantitative analyses have several implications for the study of contentious politics. First, the shift to violent tactics under state repression lends support to Lichbach's (1987) argument that the repression of nonviolent protests leads to increased levels of violence. The dynamics in Kashmir show that protesters are more likely to substitute nonviolent tactics with violent ones particularly when directly and indiscriminately repressed by the police. Once the shift to violence happens, the state's repression of violent tactics fuels further violence. Along similar lines, the significant effects of reactionary repression of nonviolent protesters in the longer term supports Opp and Roehl's (1990) micromobilization argument in the context of the protest wave in Kashmir. Even though my data do not provide direct evidence at the individual level for the occurrence of micromobilization processes, the lasting impact of reactionary repression indicates that the radical wing was able to increase its support base and engage in more violent forms of collective action even four to five days after the state repressed nonviolent dissidents. Nonetheless, the group level data fail to establish specifically that protesters in Kashmir perceived this type of repression as illegitimate and came to realize that violence was a viable option. Interviews or surveys which are designed to gather 
information regarding these processes at the individual level would present a more detailed picture regarding the micromobilization processes.

More generally, the Kashmiri case demonstrates that protest waves have the potential to transition to insurgency when contentious dynamics are combined with the fueling effects of a state's direct repression and external support. Both repression and Pakistani support became critical factors for the transition only after the contentious dynamics were already in place. Kashmiri people had experienced repression before with the curtailment of civil liberties, electoral malpractice, and intolerance to dissent in the early 1960s (Ganguly 1997). Similarly, Pakistan unsuccessfully attempted to start an armed uprising in Kashmir in 1965 but the locals failed to participate (Ganguly 1997). Thus, it is the combination of repression and external support in the context of existing contention that leads to the transition of a protest wave to an insurgency.

This study reinforces the arguments of Lichbach et al. (2003) and Tarrow (2007) that protest waves and civil wars are intimately linked. By demonstrating how reactionary repression and external support led to the transition from a protest wave to an insurgency, it provides a better understanding of how a protest wave can create its own momentum, triggering a spiral of conflict and eventually transforming into a civil war, as has recently happened in Syria and Libya. Future research needs to focus on additional cases to uncover other factors that might affect the dynamics of such transitions.

Finally, this study provides further empirical evidence for McAdam, Tarrow, and Tilly's (2001) claims that similar processes recur in various forms of political contention. In Kashmir, the transition happened as a result of fairly similar combinations of factors 
across the protest wave and insurgency stages. The state repressed the dissidents during the protest wave phase just as it subsequently did during the insurgency phase; and the dissidents used a combination of both nonviolent and violent tactics during both stages of the conflict. More importantly, however, this study confirms that contentious politics is a broader and more encompassing phenomenon than just social movements (Tarrow 2007; Tilly and Tarrow 2007). Expanding the scope of contentious politics to more violent conflicts enables scholars to understand the origins and links between different forms of political opposition. 


\section{Table 1: Summary of Hypotheses}

\begin{tabular}{lcc}
\hline \multicolumn{1}{c}{ Variable } & \multicolumn{2}{c}{ Direction of Expected Effects } \\
\hline & Immediate & Lasting \\
\hline Reactionary Repression & + & + \\
\hline Arrests & + & + \\
\hline Preventive Repression & - & - \\
\hline Accommodation & - & - \\
\hline External Support & + & + \\
\hline \hline
\end{tabular}


Table 2: Single Error Correction Model on Conflict Intensity in the Protest Wave in Kashmir (1979-1988)

\begin{tabular}{|c|c|c|}
\hline Variable & Model 1 & Model2 \\
\hline \multicolumn{3}{|l|}{ Immediate Effects (First Differences) } \\
\hline$\Delta$ Reactionary Repression of Nonviolence $(\mathrm{t})$ & $\begin{array}{l}.732 * * * \\
(.074)\end{array}$ & - \\
\hline$\Delta$ Arrest of Nonviolent Actors $_{(t)}$ & $\begin{array}{l}.137 * \\
(.066)\end{array}$ & - \\
\hline$\Delta$ Preventive Repression of Nonviolence $_{(\mathrm{t})}$ & $\begin{array}{l}.054 \\
(.063)\end{array}$ & - \\
\hline$\Delta$ Reactionary Repression of Violence $(\mathrm{t})$ & - & $\begin{array}{l}1.337 * * * \\
(.043)\end{array}$ \\
\hline$\Delta{\text { Arrest of Violent } \text { Actors }_{(t)}}$ & - & $\begin{array}{l}.993 * * * \\
(.063)\end{array}$ \\
\hline$\Delta$ Preventive Repression of Violence $(\mathrm{t})$ & - & $\begin{array}{l}.624 * * * \\
(.060)\end{array}$ \\
\hline$\Delta$ State Accommodation $_{(\mathrm{t})}$ & $\begin{array}{l}.042 \\
(.115)\end{array}$ & $\begin{array}{l}-.330 * * \\
(.095)\end{array}$ \\
\hline$\Delta$ External Support $(\mathrm{t})$ & $\begin{array}{l}1.237 * * * \\
(.080)\end{array}$ & $\begin{array}{l}.967 * * * \\
(.067)\end{array}$ \\
\hline \multicolumn{3}{|l|}{ Continuous Effects (Levels) } \\
\hline Reactionary Repression of Nonviolence $(\mathrm{t}-1)$ & $\begin{array}{l}.802 * * * \\
(.099)\end{array}$ & - \\
\hline Arrest of Nonviolent Actors $(\mathrm{t}-1)$ & $\begin{array}{l}.212 * * \\
(.078)\end{array}$ & - \\
\hline Preventive Repression of Nonviolence $(\mathrm{t}-1)$ & $\begin{array}{l}.261 * * \\
(.081)\end{array}$ & - \\
\hline Reactionary Repression of Violence (t-1) & - & $\begin{array}{l}1.564 * * * \\
(.061)\end{array}$ \\
\hline Arrest of Violent Actors(t-1) & - & $\begin{array}{l}.947 * * * \\
(.087)\end{array}$ \\
\hline Preventive Repression of Violence $(t-1)$ & - & $\begin{array}{l}.321 * * * \\
(.077)\end{array}$ \\
\hline State Accommodation $(\mathrm{t}-1)$ & $\begin{array}{l}.451^{* *} \\
(.154)\end{array}$ & $\begin{array}{l}-.274^{*} \\
(.130)\end{array}$ \\
\hline External Support $(\mathrm{t}-1)$ & $\begin{array}{l}1.130^{* * * *} \\
(.113)\end{array}$ & $\begin{array}{l}.938^{* * * *} \\
(.095)\end{array}$ \\
\hline Conflict Intensity (t-1) $($ ECM adjustment) & $\begin{array}{l}-.727 * * * \\
(.016)\end{array}$ & $\begin{array}{l}-.863 * * * \\
(.016)\end{array}$ \\
\hline Elections $_{(\mathrm{t})}$ & $\begin{array}{l}-.038 \\
(.089)\end{array}$ & $\begin{array}{l}-.007 \\
(.072)\end{array}$ \\
\hline Constant & $\begin{array}{c}-3.220 * * * \\
(.075) \\
\end{array}$ & $\begin{array}{c}-3.880 * * * \\
(.076) \\
\end{array}$ \\
\hline $\mathrm{N}$ & 3573 & 3573 \\
\hline Prob $>F$ & 0.000 & 0.000 \\
\hline Adjusted $\mathrm{R}^{2}$ & .41 & .61 \\
\hline
\end{tabular}


Table 3: Distribution of Continuous Effects on Conflict Intensity in the Protest Wave in Kashmir (1979-1988) based on Model 1

\begin{tabular}{|c|c|c|c|c|c|c|c|c|c|c|}
\hline \multirow{2}{*}{ Variable } & \multirow{2}{*}{$\begin{array}{c}\text { ECM } \\
\text { Adjst. } \\
\left(\alpha_{1}\right) \\
\end{array}$} & \multirow{2}{*}{$\begin{array}{c}\text { LRM } \\
\beta /\left(-\alpha_{1}\right) \\
\end{array}$} & \multirow{2}{*}{$\begin{array}{c}\text { Standard } \\
\text { Error }\end{array}$} & \multicolumn{7}{|c|}{ Distribution of Continuous Effects } \\
\hline & & & & $\mathbf{T}$ & $t+1$ & $t+2$ & $\mathbf{t}+\mathbf{3}$ & $\mathrm{t}+4$ & $\mathbf{t}+5$ & $t+6$ \\
\hline Reac. Rep of $(\mathrm{t}-1)$ & -.73 & 1.10 & .10 & .802 & .217 & .058 & .016 & .004 & .001 & .000 \\
\hline Arrest & -.73 & .29 & .08 & .212 & .057 & .015 & .004 & .001 & .000 & .000 \\
\hline Prev. Rep ${ }_{(t-1)}$ & -.73 & .36 & .06 & .260 & .070 & .019 & .005 & .001 & .000 & .000 \\
\hline State $\operatorname{Accom}_{(\mathrm{t}-1)}$ & -.73 & .62 & .15 & .451 & .122 & .033 & .009 & .002 & .001 & .000 \\
\hline Ext.Suppt $_{(t-1)}$ & -.73 & 1.55 & .11 & 1.130 & .305 & .082 & .022 & .006 & .002 & .000 \\
\hline
\end{tabular}




\section{Table 4: Post Estimation Simulation Results: Expected Values of Conflict Intensity in the Protest Wave in Kashmir (1979-1988) based on Model $1^{\mathrm{a}}$}

\begin{tabular}{lcccc}
\hline \hline \multicolumn{1}{c}{ Type of Effect } & $\begin{array}{c}\text { Expected Y for } \\
\text { Max. Value of X }\end{array}$ & $\begin{array}{c}\text { 95\% Confidence } \\
\text { Interval }\end{array}$ & $\begin{array}{c}\text { Expected Y for } \\
\text { Min. Value of X }\end{array}$ & $\begin{array}{c}\text { 95\% Confidence } \\
\text { Interval }\end{array}$ \\
\hline Reactionary Repression of Nonviolence & & & \\
\hline Immediate & 3.366 & $2.706,4.068$ & -3.354 & $-4.065,-2.711$ \\
\hline Longer Term & 3.662 & $2.773,4.562$ & -0.020 & $-0.065,0.028$ \\
\hline Total & 7.022 & $5.577,8.443$ & -3.381 & $-4.095,-2.733$ \\
\hline Arrest of Nonviolent Actors & 0.610 & $0.059,1.187$ & -0.570 & $-1.110,-0.039$ \\
\hline Immediate & 0.968 & $0.242,1.690$ & -0.003 & $-0.050,0.044$ \\
Longer term & 1.572 & $0.494,2.694$ & -0.580 & $-1.122,-0.043$ \\
Total & 1.693 & $0.649,2.654$ & & \\
\hline Preventive Repression of Nonviolence & & -0.009 & $-0.054,0.039$ \\
\hline Longer term & 1.940 & $0.447,3.334$ & -0.362 & $-1.189,0.455$ \\
Total & & & \\
\hline State Accommodation & 1.365 & $0.427,2.335$ & -0.002 & $-0.048,0.046$ \\
\hline Longer term & 1.494 & $0.011,3.036$ & -0.104 & $0.282,-0.672$ \\
Total & & & & \\
\hline External Support & 5.864 & $5.094,6.623$ & --5.851 & $--6.632,-5.081$ \\
\hline Immediate & 5.319 & $4.305,6.343$ & -0.025 & $-0.072,0.022$ \\
Longer term & 11.177 & $9.546,12.836$ & --5.883 & $-6.668,-5.109$ \\
\hline Total & 0.004 & $-0.038,0.049$ & 0.004 & $-0.038,0.049$ \\
\hline Baseline Model ${ }^{b}$ & & & & \\
\hline \hline
\end{tabular}

${ }^{a}$ Expected values of conflict intensity are derived from maximum and minimum values of each independent variable when all others are held at their means, except for the dummy variables.

${ }^{\mathrm{b}}$ The baseline model is generated with all the independent variables held at their mean values. 
Table 5: Evolution of Collective Action during the Protest Wave in Kashmir (1979-1988)

\begin{tabular}{lccc}
\hline \hline \multicolumn{1}{r}{ Type of Action } & \multicolumn{3}{c}{ Time Period } \\
\hline Nonviolent strikes & $\mathbf{1 9 8 6}$ & $\mathbf{1 9 8 7}$ & $\mathbf{1 9 8 8}$ \\
Nonviolent demonstrations & 25 & 22 & 6 \\
Violent Strikes & 48 & 29 & 28 \\
Violent Demonstrations & 3 & 9 & 23 \\
Clashes & 19 & 9 & 34 \\
Bombings & 9 & 36 & 24 \\
Burning houses and villages & 4 & 1 & 13 \\
\hline \hline
\end{tabular}


Figure 1: Protest Wave in Kashmir (1979-1988) ${ }^{c}$

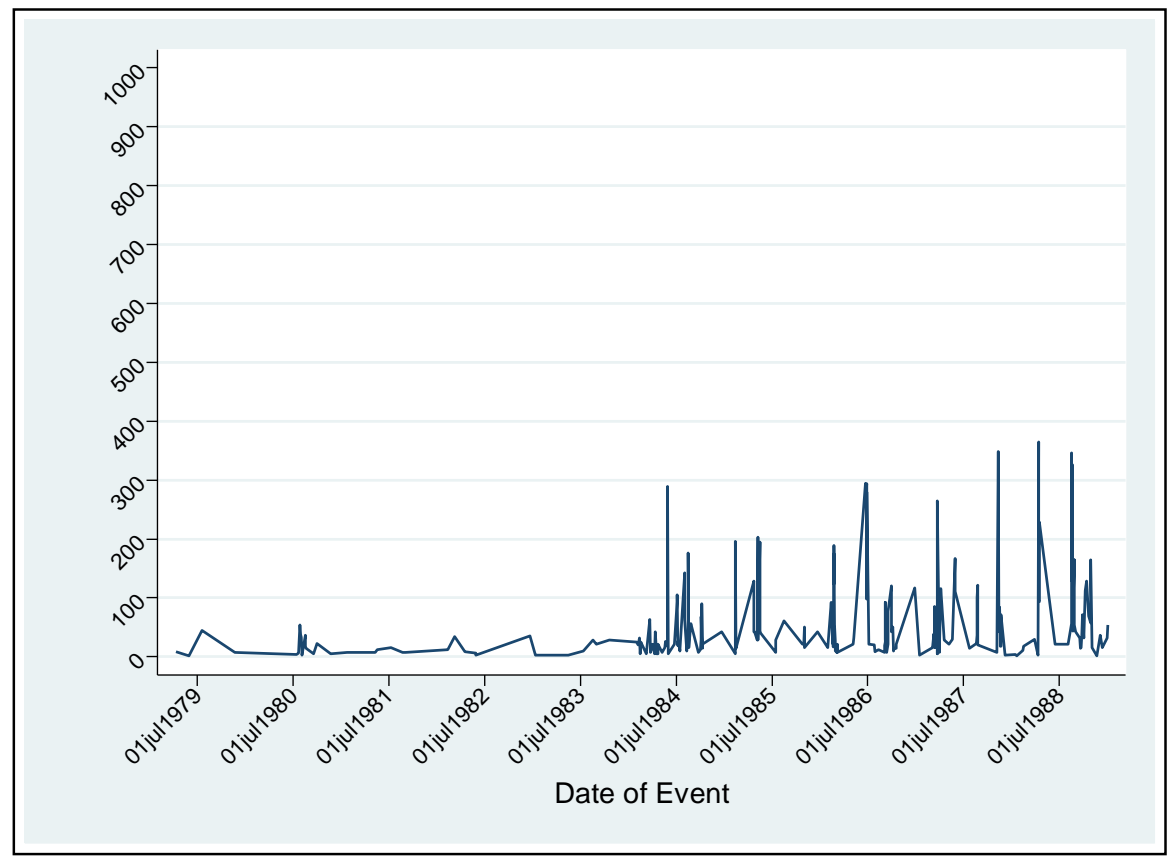

Note: ${ }^{c}$ This figure is based on the original dataset and is produced by using the weighted scale of collective action. 
Figure 2: Transition from Protest Wave to Insurgency

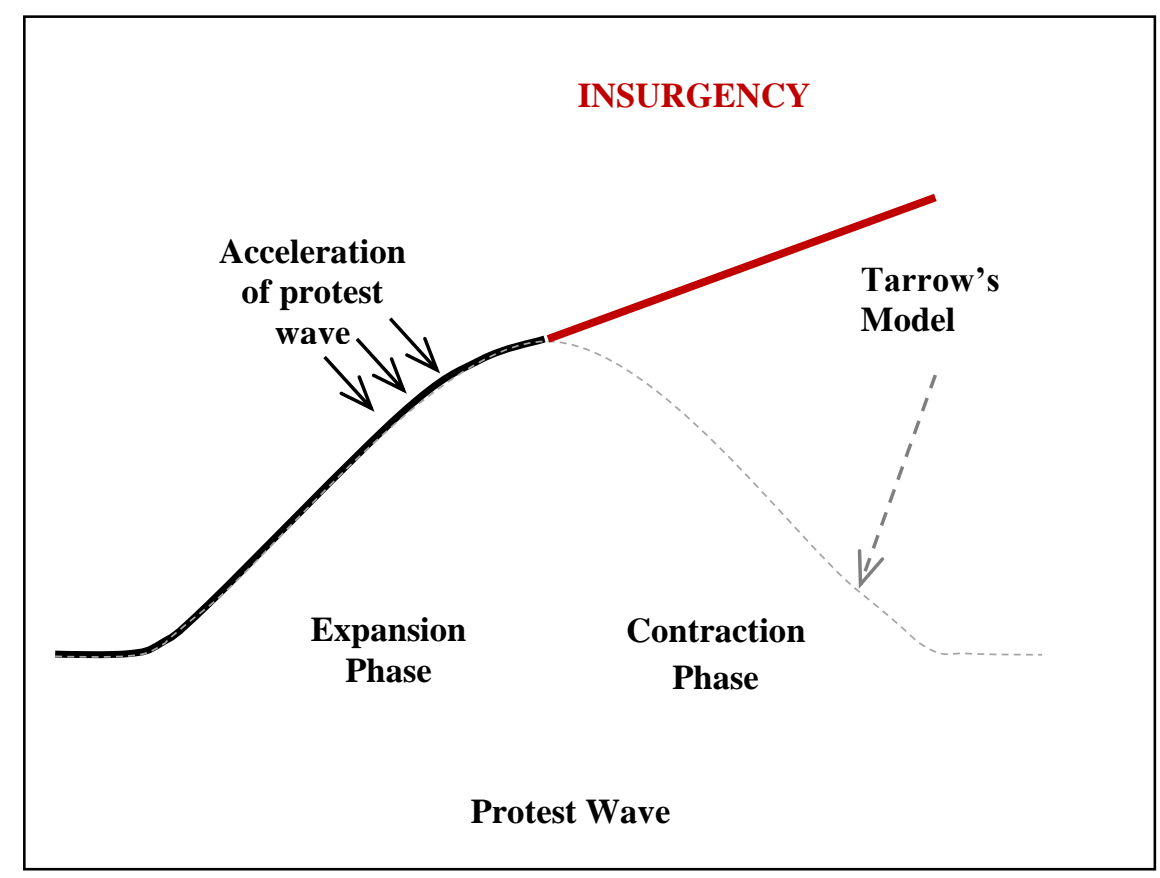

\section{REFERENCES}

"30 Hurt as 'Kashmir Bandh' turns violent". 1987. The Hindu, November 21.

Almeida, Paul. 2008. Waves of Protest : Popular Struggle in El Salvador, 1925-2005.

Minneapolis: University of Minnesota Press.

Beissinger, Mark R. 2002. Nationalist Mobilization and the Collapse of the Soviet State. Cambridge: Cambridge University Press.

2011. Mechanisms of Maidan: The Structure of Contingency in the Making of the Orange Revolution. Mobilization 16 (1):25-43. 
Brockett, Charles D. 2005. Political Movements and Violence in Central America. Cambridge: Cambridge University Press.

Collier, Paul, and Anke Hoeffler. 2004. Greed and Grievance in Civil War. Oxford Economic Papers 56 (4):563-595.

De Boef, Suzanna, and Luke Keele. 2008. Taking Time Seriously. American Journal of Political Science 52 (1):184-200.

della Porta, Donatella, and Sidney Tarrow. 1986. Unwanted Children: Political Violence and the Cycle of Protest in Italy: 1966-1973. European Journal of Political Research 14.

Entropy Increasing. 2012. The Economist, September 15.

Fearon, James D., and David D. Laitin. 2003. Ethnicity, Insurgency, and Civil War. American Political Science Review 97 (1):75.

Francisco, Ronald A. 1995. The Relationship between Coercion and Protest: An Empirical Evaluation in Three Coercive States. The Journal of Conflict Resolution 39 (2):263-282.

Ganguly, Sumit. 1997. The Crisis in Kashmir: Portents of War, Hopes of Peace. Cambridge: Cambridge University Press.

Gleditsch, Kristian Skrede. 2007. Transnational Dimensions of Civil War. Journal of Peace Research 44 (3):293-309.

Goodwin, Jeff. 2001. No Other Way Out: States and Revolutionary Movements, 19451991. New York: Cambridge University Press. 
Granovetter, Mark. 1978. Threshold Models of Collective Behavior. The American Journal of Sociology 83 (6):1420-1443.

Heraclides, Alexis. 1990. Secessionist Minorities and External Involvement. International Organization 44 (3):341-378.

Inclan, Maria de la Luz. 2009. Repressive Threats, Procedural Concessions, and the Zapatista Cycle of Protests, 1994-2003. Journal of Conflict Resolution 53 (5):794819.

Kalyvas, Stathis N. 2005. Warfare in Civil Wars. In Rethinking the Nature of War, edited by I. Duyvesteyn and J. Angstrom. New York: Frank Cass.

—. 2006. The Logic of Violence in Civil War. Cambridge: Cambridge University Press.

Khawaja, Marwan. 1993. Repression and Popular Collective Action: Evidence from the West Bank. Sociological Forum 8 (1):47-71.

Klandermans, Bert. 1984. Mobilization and Participation: Social-Psychological Expansions of Resource Mobilization Theory. American Sociological Review 49 (5):583-600.

Koopmans, Ruud. 1997. Dynamics of Repression and Mobilization: The German Extreme Right in the 1990s. Mobilization 2 (2):149-165.

Krain, Matthew. 2000. Repression and Accommodation in Post-Revolutionary States. 1st ed. New York: St. Martin's Press.

Lichbach, Mark I, Christian Davenport, and David A. Armstrong. 2003. Contingency, Inherency, and the Onset of Civil War. Draft. 
Lichbach, Mark Irving. 1987. Deterrence or Escalation? The Puzzle of Aggregate Studies of Repression and Dissent. The Journal of Conflict Resolution 31 (2):266-297.

McAdam, Doug. 1983. Tactical Innovation and the Pace of Insurgency. American Sociological Review 48 (6):735-754.

-1988. Micromobilization Contexts and Recruitment to Activism. International Social Movement Research 1:125-154.

McAdam, Doug, and Sidney Tarrow. 2010. Ballots and Barricades: On the Reciprocal Relationship beteen Elections and Social Movements. Perspectives on Politics 8 (2):529-542.

McAdam, Doug, Sidney G. Tarrow, and Charles Tilly. 2001. Dynamics of Contention. New York: Cambridge University Press.

McCarthy, John D., and Mayer N. Zald. 1977. Resource Mobilization and Social Movements: A Partial Theory. The American Journal of Sociology 82 (6):12121241.

Moore, Will H. 1998. Repression and Dissent: Substitution, Context, and Timing. American Journal of Political Science. 42 (3):851.

MUF Call to Scrap Accession. 1987. The Indian Express, August 21.

Oberschall, Anthony R. 1994. Rational Choice in Collective Protests. Rationality and Society 6 (1):79-100.

Opp, Karl-Dieter, and Wolfgang Roehl. 1990. Repression, Micromobilization, and Political Protest. Social Forces 69 (2):521-547. 
Papke, Leslie E., and Jeffrey M. Wooldridge. 1996. Econometric Methods for Fractional Response Variables With an Application to 401 (K) Plan Participation Rates. Journal of Applied Econometrics 11 (6):619-632.

Patankar, V.G. 2009. Insurgency, Proxy War, and Terrorism in Kashmir. In India and Counterinsurgency : Lessons Learned, edited by S. Ganguly and D. P. Fidler. New York: Routledge.

Rasler, Karen. 1996. Concessions, Repression, and Political Protest in the Iranian Revolution. American Sociological Review 61 (1):132-152.

Salehyan, Idean. 2009. Rebels Without Borders: Transnational Insurgencies in World Politics. Ithaca: Cornell University Press.

Sambanis, Nicholas, and Annalisa Zinn. 2006. From Protest to Violence: An Analysis of Conflict Escalation with an Application to Self Determination Movements. Draft. Schofield, Victoria. 2003. Kashmir in Conflict: India, Pakistan and the Unending War. New ed. London: I.B. Tauris.

Shellman, Stephen M. 2006. Process Matters: Conflict and Cooperation in Sequential Government-Dissident Interactions. Security Studies 15 (4):563-599.

Snow, Donald M. 1996. Uncivil Wars: International Security and the New Internal Conflicts. Boulder: Lynne Rienner.

Snyder, Jack L. 2000. From Voting to Violence : Democratization and Nationalist Conflict. New York: Norton.

Staniland, Paul. 2012. Organizing Insurgency: Networks, Resources, and Rebellion in South Asia. International Security 37 (1):142-177. 
Swami, Praveen. 2007. India, Pakistan and the Secret Jihad: The Covert War in Kashmir, 1947-2004. London: Routledge.

Tarrow, Sidney G. 1989. Democracy and Disorder : Protest and Politics in Italy, 19651975. Oxford: Oxford University Press.

-1998. Power in Movement: Social Movements and Contentious Politics. 2nd ed. Cambridge: Cambridge University Press.

_. 2007. Inside Insurgencies: Politics and Violence in an Age of Civil War. Perspectives on Politics 5 (3):587-600.

Thyne, Clayton. 2006. Cheap Signals with Costly Consequences: The Effect of Interstate Relations on Civil War. The Journal of Conflict Resolution 50 (6):937-961.

Tilly, Charles. 1978. From Mobilization to Revolution. Reading: Addison-Wesley Pub.Co.

Tilly, Charles, and Sidney G. Tarrow. 2007. Contentious Politics. Boulder: Paradigm Publishers.

Tomz, Michael, Jason Wittenberg, and Gary King. 2003. CLARIFY:Software for Interpreting and Presenting Statistical Results. Journal of Statistical Software 8.

White, Robert W. 1989. From Peaceful Protest to Guerrilla War: Micromobilization of the Provisional Irish Republican Army. The American Journal of Sociology 94 (6):1277-1302. 


\section{NOTES}

${ }^{1}$ No other major historical events such as interstate disputes between India, China, or Pakistan occurred during the time under investigation that can be considered as a rival explanation.

${ }^{2}$ This is a narrower definition than della Porta and Tarrow's (1986) as it includes only nonviolent forms of collective action.

${ }^{3}$ The correlation coefficients for all variables between the number of events and the weighted data are above .96 .

${ }^{4}$ The codebook used for the dataset is posted as Appendix A.

5 From October 15, 1987 until December 3, 1987, Indian Express published no issues. For this time period, The Hindu was used as the major news source.

${ }^{6}$ The descriptive statistics for the variables and the overtime patterns of violent and nonviolent collective action, repression, accommodation, and external support are provided in Appendix B.

7 A logit transformation $(\ln [y / 1-y])$ is useful when the dependent variable is a proportion and is bounded by 0 and 1 , smoothening the variable and fitting it on a real line so that it can be appropriately used in OLS (Papke and Wooldridge 1996). To avoid missing values (due to $y=0$ or $y=1$ ), I added .01 to the variable if $y=0$ and subtracted .01 if $y=1$.

${ }^{8}$ Except for the dummy variables, all the independent variables are logged to reduce the skewness in the variables. A constant value of 1 was added to all daily scores.

${ }^{9}$ For the 1983 and 1987 state assembly elections, the periods between January 1 and April 30 are each coded 1. Ideally, I would control for the interaction between elections 
and repression as well since elections can increase state repression if the government chooses to crack down on the opposition in order to remain in power. The distinction between different categories of repression on different types of actions and the aggregation of the events on daily bases leave few observations for each category. Hence, I do not include those interaction variables in the model. When the analysis is run with the interactions of all three types of repression regardless of the target, they are mostly insignificant.

${ }^{10}$ For a comprehensive discussion of the consequences of restricting the model by taking out the short term or long term effects, see DeBoef and Keele (2008).

11 The lag length is determined by the Akaike information criterion (AIC) scores. In addition, I ran these models by including lags up to 7 days ( $t-7)$ to make sure that the coefficients for the variables did not have significant and consistent effects at long lags. The analyses with longer lags can be found in Appendix C.

12 This ECM is an ordinary least squares equation.

${ }^{13}$ As accommodation in Kashmir only targeted nonviolent groups, a distinction between targets was not made. The same logic also applies to external support from Pakistan, which only targeted violent actors.

${ }^{14}$ Appendix C provides single ECMs with nonviolent mobilization and total mobilization as the dependent variables. The analyses suggest that the dynamics of total mobilization are similar to those of conflict intensity as total mobilization is also driven by reactionary repression, arrests, and external support. Models on nonviolent mobilization suggest that preventive repression has both short and long term positive effects on nonviolent 
mobilization while external support does not. Event count models for robustness checks of violent and total mobilization also largely confirm the main findings of the ECM on conflict intensity.

${ }^{15}$ Both Autocorrelation Function and Partial Autocorrelation Function plots indicate that the residuals are not autocorrelated.

${ }^{16}$ Although protests effectively start in 1984 , the analysis goes back to 1979 to account for any earlier protest dynamics. Running the ECM for 1984-1988 reveals similar results. ${ }^{17}$ The standard errors of the LRMs computed by Bewley transformation indicate that the LRMs are all significant.

${ }^{18}$ These simulations were estimated by CLARIFY: Software for Interpreting and Presenting Statistical Results (Tomz, Wittenberg, and King 2003).

${ }^{19}$ Only the effects of significant coefficients are reported in Table 4.

${ }^{20}$ The election dummy variable was held at 0 .

${ }^{21}$ Given the systemic underreporting of external support, these results are probably underestimating the effects of this variable.

${ }^{22}$ The results of a single ECM on conflict intensity that includes the repression of both nonviolence and violence can be found in Appendix D. While this model mostly confirms the findings of Model 1 and 2, reactionary repression of nonviolence loses significance in the combined model, possibly due to multicollinearity. 